\title{
Reply to letter to the editor by De Michele et al
}

\author{
A. Nazli Basak ${ }^{1}$ (I)
}

Received: 21 January 2020 / Accepted: 28 January 2020 / Published online: 6 February 2020

(C) Springer-Verlag GmbH Germany, part of Springer Nature 2020

\section{Dear Editor,}

We are grateful to De Michele et al. for their enlightening and constructive comments on our study on c.823_824delCTbased SCA48, which seems to be a recurrent dominant ataxia in the Mediterranean Basin; we have just identified another Turkish patient with SCA48, although with a different STUB1 variant $[1,2]$.

We would like to address the comments on the c. 823 824delCT SCA48 mutation, the subject of our discussion.

Although both De Michele et al.'s case and our case have chorea as an accompanying disease symptom [3], in Huntington disease-like (HDL) syndromes, chorea is a significant core clinical sign. However, in our family, chorea is a minor, very late onset, and accompanying symptom. The fact that Genis' original cases do not have chorea at all does also not suggest an HDL syndrome [1].

The number of c. 823 824delCT-based SCA48 cases is limited to the original family of Genis et al.,

De Michele et al.'s patient, and the single Turkish case. Our patient's clinical phenotype regarding the cognitive-affective aspect of c.823_824delCT-based SCA48 is fully consistent with the Genis' family, except for Genis' case VII-1, who belongs to the younger generation of the family and may not yet have manifested the full-blown disease [1,2]. De Michele et al.'s patient 10 presenting with pure cerebellar ataxia as an initial symptom, typical for SCAs, has overlapping symptoms with our patient, but these symptoms manifest in a different temporal profile [4].

Genis' and our cases presenting with CAS (Cognitive Affective Syndrome), on the other hand, give a crucial message to the clinicians: In a slowly progressive cognitively impaired patient with frontal manifestations and accompanying affective symptoms, especially showing supportive imaging findings (involving the cerebellum and its connections), the

A. Nazli Basak

nbasak@ku.edu.tr

1 Koc Universitesi, Istanbul, Turkey possible etiology of a cerebellar degenerative disorder should be considered. Our patient initially had frontal cognitive and affective symptoms with MRI findings, depicting cerebellar atrophy, preceding the cerebellar motor symptoms for many years.

Although DTI is not a routine tool in evaluating patients, in clinically challenging complex cases, DTI may add further valuable information on the anatomical tracts affected, as it was in our case.

Of course, we definitely agree with De Michele et al.'s statement that the identification of further SCA48 cases is crucial to examine current notions on the relationship between the cerebellum and cognitive dysfunction in the spinocerebellar disorders.

\section{References}

1. Genis D, Ortega-Cubero S, San Nicolás H, Corral J, Gardenyes J, de Jorge L, López E, Campos B, Lorenzo E, Tonda R, Beltran S, Negre M, Obón M, Beltran B, Fàbregas L, Alemany B, Márquez F, RamióTorrentà L, Gich J, Volpini V, Pastor P (2018) Heterozygous STUB1 mutation causes familial ataxia with cognitive affective syndrome (SCA48). Neurology 91:e1988-e1998. https://doi.org/10.1212/ WNL.0000000000006550

2. Palvadeau R, Kaya-Güleç ZE, Șimșir G, Vural A, Öztop-Çakmak Ö, Genç G, Aygün MS, Falay O, Başak AN, Ertan S (2020) Cerebellar cognitive-affective syndrome preceding ataxia associated with complex extrapyramidal features in a Turkish SCA48 family. Neurogenetics 21:51-58. https://doi.org/10.1007/s10048-01900595-0

3. De Michele G, Lieto M, Galatolo D, Salvatore E, Cocozza S, Barghigiani M, Tessa A, Baldacci J, Pappatà S, Filla A, De Michele G, Santorelli FM (2019) Spinocerebellar ataxia 48 presenting with ataxia associated with cognitive, psychiatric, and extrapyramidal features: a report of two Italian families. Parkinsonism Relat Disord. https://doi.org/10.1016/j.parkreldis.2019.05.001

4. Lieto M, Riso V, Galatolo D, De Michele G, Rossi S, Barghigiani M, Cocozza S, Pontillo G, Trovato R, Saccà F, Salvatore E, Tessa A, Filla A, Santorelli FM, De Michele G, Silvestri G (2019) The complex phenotype of spinocerebellar ataxia type 48 in eight unrelated Italian families. Eur J Neurol. https://doi.org/10.1111/ene.14094

Publisher's note Springer Nature remains neutral with regard to jurisdictional claims in published maps and institutional affiliations. 